\title{
最近の気象データによる全国冷暖房負荷の変動
}

-戸建住宅＼cjkstart全国の 1991 ～ 2017 年の年間冷暖房負荷、ピーク負荷の推移-

\section{ANALYTICAL STUDY OF COOLING AND HEATING LOADS DUE TO RECENT NATIONWIDE WEATHER DATA}

Changes in cooling and heating loads and peak loads of the detached house during the year from 1991 to 2017

\section{磯崎 恭一郎*1, 武田 仁*2 \\ Kyoichiro ISOZAKI and Hitoshi TAKEDA}

\begin{abstract}
The authors focused on the influence of recent weather changes on cooling and heating loads, then created data from JMA observation data of 30 locations nationwide from 1991 to 2017 (27 years) recently.

Using these data, the cooling and heating loads of the detached house are strictly calculated using the thermal load calculation program (LESCOM-mint).

(1) Annual cooling loads increase both in cities and elsewhere.

(2) Annual heating loads are decreasing due to secular change, but there are some points where it is increasing.

(3) The instantaneous cooling loads increase at 29 locations, excluding one point Kofu.
\end{abstract}

Keywords : Annual heating and cooling loads, Instantaneous heating and cooling loads, Heat island, LESCOM, Weather data, Detached house model 年間冷暖房負荷, 瞬時冷暖房負荷, ヒートアイランド, レスコム, 気象データ, 戸建住宅モデル

\section{1. はじめに}

気象庁「気候変動監視レポート2016」1)によると日本の年平均気温 は上昇し，真夏日，猛暑日は増加傾向にあり都市はヒートアイラン ド化が進んでいると報告している。

ヒートアイランドの研究は竹林英樹ら 2)の「メソ気象モデル WRF を用いた海岸に立地する都市の規模と夏期のヒートアイランド強度 の関係分析」，足永靖信ら ${ }^{3)}$ の「地球シミュレータを用いた東京都心 $10 \mathrm{~km}$ 四方における高解像度のヒートアイランド数值解析」, 梅干野 晃ら ${ }^{4)}$ 「熱収支シミュレーションによる市街区単位の夏季と冬季 ヒートアイランドポテンシャルの解析」等多数があり, 気象と建物 外皮温度, 地表面温度の解析を行っている。また, 曽我和弘 5)の「地 球温暖化予測情報第 6 巻に基づく標準年将来気象データの空調熱負 荷への応用」, 有馬雄祐ら ${ }^{6)}$ の「夏季の関東地方を対象とした近未来 標準気象データの試作と気候変動の建築負荷への影響評価力学的ダ ウンスケーリングによる建築熱負荷のための近未来気象データの作 成」では将来気象データを論じている。

筆者ら》は最近の気象変動が冷暖房負荷に与える影響に注目し， 「気象指標に基づく近未来冷暖房負荷の予測 東京の最近 50 年間 よりのオフィス年間冷暖房負荷の予測」では冷房負荷が経年で増加
し，暖房負荷が減少すると報告した。

これまでの気象庁の気像データファイル化は赤坂ら 8)の「拡張ア メダス気象データ」, 筆者ら 9)の「全国気象データと熱負荷計算プロ グラム LESCOM」等がある。

筆者らは最近の気象庁の地上気象データのうちの日射量が観測さ れ，比較的欠測の少ない $1991 \sim 2017$ 年（27 年間），30 地点を選び 戸建住宅を厳密に冷暖房負荷計算を行った。冷暖房負荷は気象変動 および建物条件, 内部発熱, 空調の運転状況により算定される。 最近の急激な気象データ変動の経年変化が冷暖房負荷に及ぼす影 響をまとめたので報告する。

\section{2. 気象データの作成}

気象庁公表の「過去の気象データ・ダウンロード」10)を用いる。 気象要素は気温, 湿度, 日射量, 雲量, 風向, 風速とする。

\section{1 気象要素}

1)絶対湿度変換

観測露点温度より ASHRAE の方法(Wexler-Hyland の式)を用いる。 $\begin{array}{ll}* 1 & \text { (株レスコム研究所 } \\ * 2 & \text { 東京理科大学 名誉教授. 工博 }\end{array}$
LESCOM Institute Co., Ltd.

Prof. Emeritus, Tokyo University of Science, Dr.Eng. 


\section{2)太陽視赤緯・均時差}

海上保安庁海上情報部の式を用いる ${ }^{11)}$ 。

3)法線面直達日射量, 水平面天空日射量の分離

観測水平面全天日射量より Reindl の式 12)を用いて, 法線面直達日 射量，水平面天空日射量に分離する。

4)雲量補完

3 時間間隔観測データより 1 時間間隔に直線補間する。

\section{5)FORMAT}

気象データの FORMAT は HASP FORMAT（空気調和衛生工学会 方式）13）とする。

\section{2 全国 30 地点の気象データ作成}

1991〜2017 年の 27 年間 1 年毎に作成し, 多数の欠測がある場合そ の年は作成しなかった。なお, 気象庁の文献 10 は全天日射量の観測 地点は全国で約 50 地点, また日射量公開開始日等を考慮して, 30 地 点, 1991 年以降を作成した。

作成状況を Table1 に示す。

作成地点は稚内, 網走, 旭川, 札幌, 函館, 青森, 盛岡, 秋田, 仙 台，新潟，甲府，銚子，東京，名古屋，大阪，広島，下関，高松， 松山, 福岡, 長崎, 熊本, 大分, 宮崎, 鹿児島, 名瀬, 那覇, 石垣 島, 宮古島, 父島である。

Table1 Creating situation of 30 weather points

\begin{tabular}{|c|c|c|}
\hline $\begin{array}{l}\text { Region } \\
\text { classfication }\end{array}$ & Point & Year not created \\
\hline \multirow{3}{*}{-1} & WAKKANAI & - \\
\hline & ABASHIRI & - \\
\hline & ASAHIKAWA & 2009 \\
\hline \multirow{2}{*}{2} & SAPPORO & - \\
\hline & HAKODATE & 2014 \\
\hline \multirow{3}{*}{3} & AOMORI & 2011,2014 \\
\hline & MORIOKA & - \\
\hline & AKITA & - \\
\hline 4 & SENDAI & - \\
\hline \multirow{2}{*}{5} & NIIGATA & - \\
\hline & KOFU & - \\
\hline \multirow{12}{*}{6} & $\mathrm{CHOSHI}$ & - \\
\hline & TOKYO & - \\
\hline & NAGOYA & - \\
\hline & OSAKA & - \\
\hline & HIROSHIMA & - \\
\hline & SHIMONOSEKI & 2010 \\
\hline & \begin{tabular}{|l} 
TAKAMATSU \\
\end{tabular} & - \\
\hline & MATSUYAMA & - \\
\hline & FUKUOKA & - \\
\hline & NAGASAKI & 2013 \\
\hline & KUMAMOTO & $2012,2013,2015$ \\
\hline & OITA & 2012 \\
\hline \multirow{2}{*}{7} & MIYAZAKI & $2010,2011,2012,2013$ \\
\hline & KAGOSHIMA & 2010 \\
\hline \multirow{5}{*}{8} & NAZE & 2010,2013 \\
\hline & NAHA & - \\
\hline & ISHIGAKIJIMA & 2013 \\
\hline & MIYAKOJIMA & 2014 \\
\hline & CHICHIJIMA & 2012 \\
\hline
\end{tabular}

3.シミュレーション条件

\section{1 断熱仕様}

建物条件は宇田川モデル 14)を基に一部修正を加えた。 断熱水準を 3 水準とした。戸建住宅図をFig.1, 断熱水準をTable2, 各部屋床面積を Table3 に示す。
Table2 Thermal insulation level of detached house

\begin{tabular}{|c|c|c|c|}
\cline { 2 - 4 } \multicolumn{1}{c|}{} & Adiabatic level1 & Adiabatic level2 & Adiabatic level3 \\
\hline Outer wall insulation & None & Glasswool $50 \mathrm{~mm}$ & Glasswool $150 \mathrm{~mm}$ \\
\hline Aperture & $\begin{array}{c}3 \mathrm{~mm} \text { Transparent single } \\
\text { plate glass }\end{array}$ & $\begin{array}{c}3+\mathrm{A} 6+3 \mathrm{~mm} \text { Transparent } \\
\text { multilayer }\end{array}$ & $\begin{array}{c}3+\mathrm{A} 6+3 \mathrm{~mm} \text { LowE } \\
\text { multilayer }\end{array}$ \\
\hline Heat loss coefficient $\left(\mathrm{W} / \mathrm{m}^{2} \cdot \mathrm{K}\right)$ & 2.543 & 1.505 & 1.311 \\
\hline
\end{tabular}

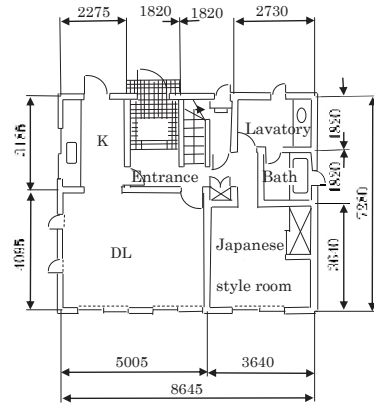

First floor plan

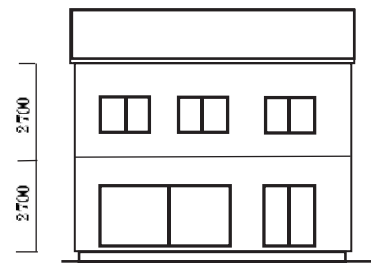

South elevation view
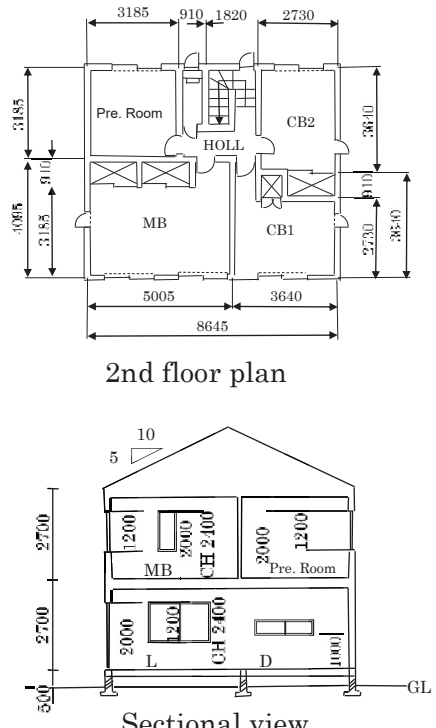

Sectional view
Fig. 1 Detached house figure

\section{2 開口部仕様}

開口部：モデルのサイズよりもやや大きくした。断熱水準 $1 ， 2$ の 遮蔽物はブラインド(横型 $25 \mathrm{~mm}$ ，明色，平板反射率 $72.76 \%$ ，スラ ット角度 $<$ 夏季 $>+45^{\circ}$ <冬季 $>-45^{\circ}$ )とした。

\section{3 設定温湿度, 内部発熱スケジュール \\ Table3 Floor area of 設定温湿度 each room}

夏季 $26{ }^{\circ} \mathrm{C}, 50 \%$

空調運転スケジュール

$\mathrm{LDK}$ : 6 時〜 14 時, 16 時〜 22 時 $\mathrm{MB}$ (主寝室)：21 時〜 23 時 CB1(子供室 1), CB2(子供室 2)：

\begin{tabular}{|l|l|r|}
\hline \multicolumn{1}{|c|}{} & Room name & Floor area( $\left.\mathrm{m}^{2}\right)$ \\
\hline \multirow{4}{*}{ 1F } & LD(Dining Living) & 20.49 \\
\cline { 2 - 3 } & K(kitchen) & 7.23 \\
\cline { 2 - 3 } & Japanese style Room & 13.2 \\
\cline { 2 - 3 } & Other & 21.96 \\
\cline { 2 - 3 } Subtotal & 62.93 \\
\hline \multirow{5}{*}{ 2F } & 20.49 \\
\cline { 2 - 3 } & MB(Main Bedroom) & 11.59 \\
\cline { 2 - 3 } & CB1(Child Bedroom1) & 11.59 \\
\cline { 2 - 3 } & CB2(Child Bedroom2) & 10.14 \\
\cline { 2 - 3 } & Preparatory Room & 9.12 \\
\cline { 2 - 3 } & Other & 62.93 \\
\cline { 2 - 3 } & Subtotal & 125.86 \\
\hline & &
\end{tabular}
20 時〜 22 時

昼夜設定温度が異なる熱負荷計算法注 1)を用いる。 内部発熱およびスケジュールを Fig.2-1，2-2 に示す。

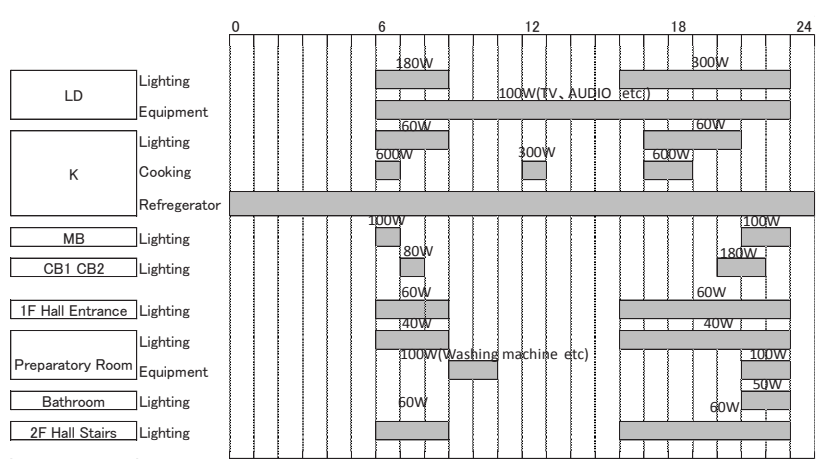

Fig. 2-1 Internal heat generation and schedule (Part 1) 

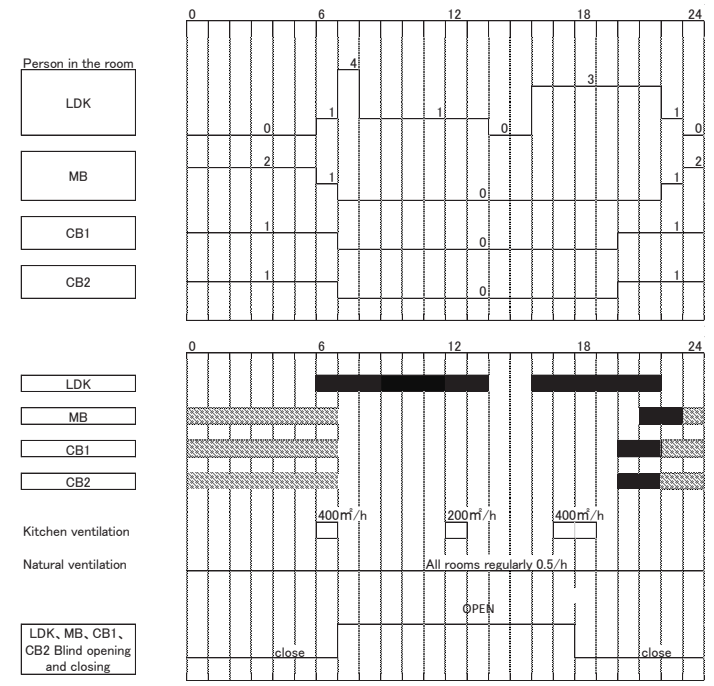

Cooling Temp. $26^{\circ} \mathrm{C}:$ Heating Temp. $22^{\circ} \mathrm{C}$

$18^{\circ} \mathrm{C}$ or more and $28^{\circ} \mathrm{C}$ or less compensated

Fig. 2-2 Internal heat generation and schedule (Part 2)

\section{4. 熱負荷計算プログラム}

熱負荷計算プログラムは LESCOM-mint9)を用いる。 特徴

1)レスポンスファクタ・ウェイティングファクタ法による多数室 非定常計算。

2)開口部のブラインドの光学特性に Radiance ${ }^{15)}$ を用いる。

3)予熱，予冷計算に文献 16)を用いる。

4)今回，設定温度が異なる計算方法注 1)を追加する。

$5)$ 気象データ 1 時間間隔を 1 分間隔に直線補完し利用する。

5. シミュレーション結果

各地点計算時間間隔は 1 分とし, 蓄熱を考慮し夏季の気象データ より始め日積算冷房負荷が 3 日間引き続きない日の翌日より暖房を 開始した。同様に当年の日積算暖房負荷が 3 日間引き続きない日の 翌日より泠房を開始した注2)。詳細計算例として 2014 冬季，2015 夏 季冬季，2016 夏季冬季，2017 夏季の各冷暖房負荷を示す。次いで, 27 年間のシミュレーション結果を示す。なお, 暖房負荷は発生する 年から翌年の終了する春までを言い発生する年の冬季と記述する。 また，負荷とは顕熱+潜熱の和の全熱負荷を言う。

\section{1 瞬時冷暖房負荷の解析}

(1) 瞬時冷暖房負荷の高順位

2014 ・2015 • 2016 の冬季, 2015 ・ 2016・2017 の夏季, 各シーズン の建物全体の瞬時冷暖房の 1 位より 2160 位迄 (36 時間分) を大きい 順を Fig. 3 に示す。 1 分間隔計算の高順位から低順位への変動は滑 らかな減衰をしている。瞬時冷暖房の高負荷の考察は 1 位および安 定した負荷の 720 位を用いる。なお 1 分間隔計算の 720 位は 12 時 間目に当たる。

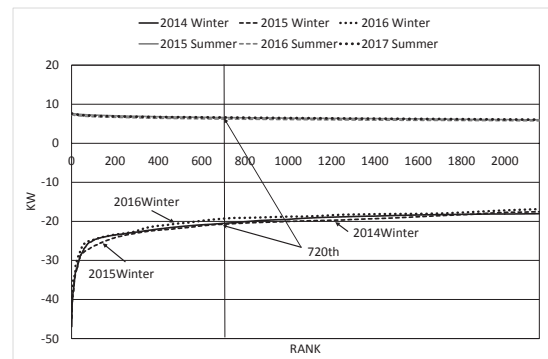

Fig. 3 Instantaneous cooling and heating loads to the top 2160 positions (Tokyo recent 3 seasons)

(2) 瞬時冷暖房負荷 1 位

断熱水準 2 の東京 3 シーズンの上位 1 位を Fig. 4 に示す。いずれ の年も冷房は夕方 17 時 1 分，暖房は立ち上がりの 6 時 1 分になっ た。

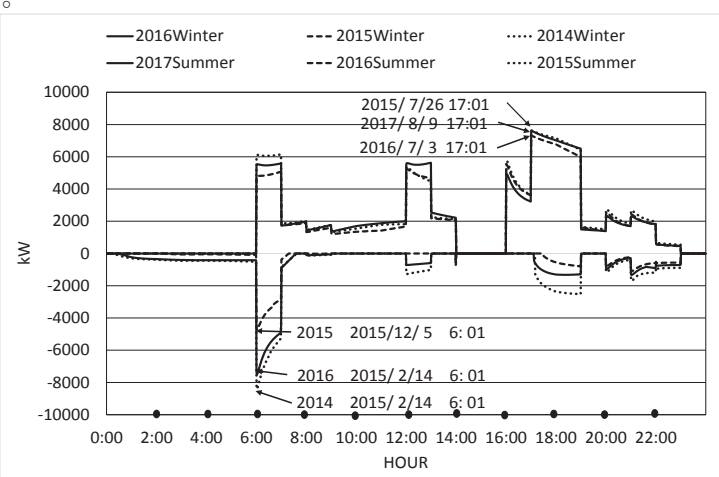

Fig. 4 1st of instantaneous cooling and heating loads of insulation level 2 (3 seasons in Tokyo)

(3) 瞬時冷暖房負荷 720 位

断熱水準 2 の東京 3 シーズンの 720 位建物冷暖房負荷の時刻変動 をFig. 5 に示す。冷暖房負荷変動は 3 シーズンとも 1 位とほぼ同様 の変動をする。

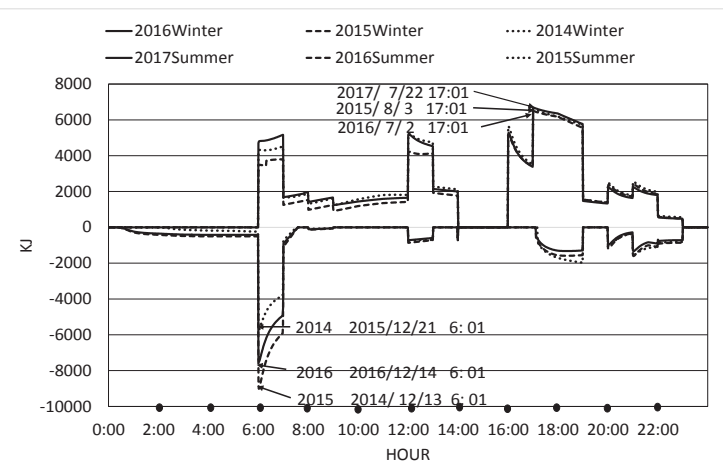

Fig. 5 720th of instantaneous cooling and heating loads of insulation level 2 (3 seasons in Tokyo)

（4）上位 720 位の各スペース冷暖房負荷

2017 年, 断熱水準 2 の東京瞬時上位 720 位の各スペース (K, LD, MB, CB1, CB2) の冷暖房負荷を Fig. 6 に示寸。住宅の生活パタ ーンによる冷暖房負荷の変化が激しいのが分かる。 


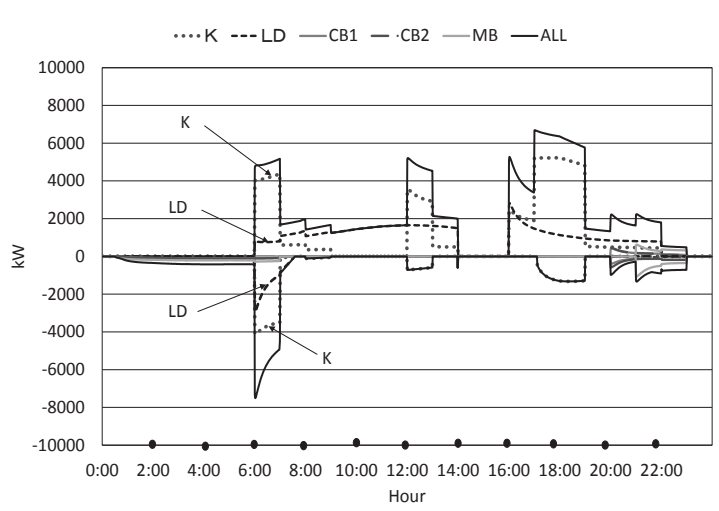

Fig. $6720^{\text {th }}$ of instantaneous cooling and heating loads of each space in Tokyo

\section{(5) 瞬時冷暖房負荷の分布}

断熱水準 2 の 1 位および 720 位の瞬時冷暖房負荷が発生した時 刻を Fig. 7-1, 7-2, 7-3, 7-4, 7-5, 7-6 の 1 年時間軸に示す。冷 房負荷は 7 月上旬から 9 月中旬にまとまっているのに対し暖房負 荷は 11 月中旬から 3 月上旬と分散している。

\section{SAPPORO}

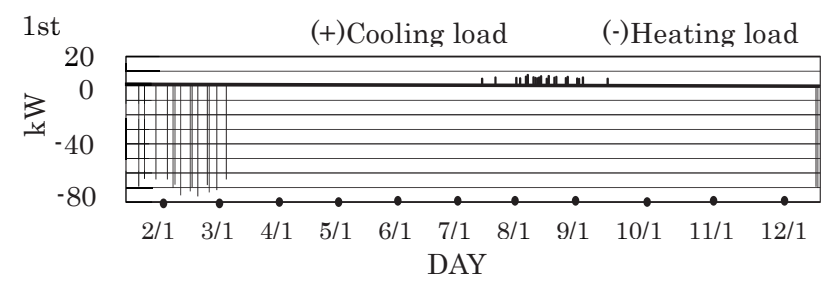

Fig. 7-1 1st of Distribution of instantaneous cooling and heating loads in Sapporo

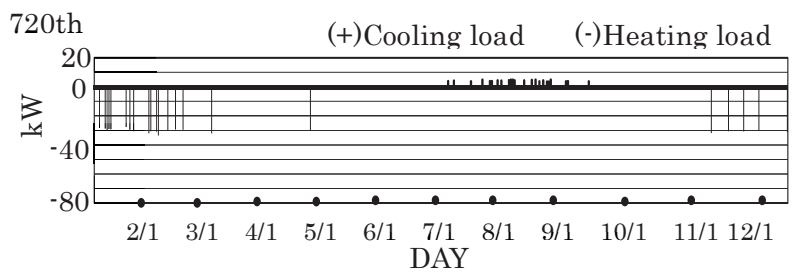

Fig. 7-2 $720^{\text {th }}$ of Distribution of instantaneous cooling and heating loads in Sapporo

\section{TOKYO}

1 st

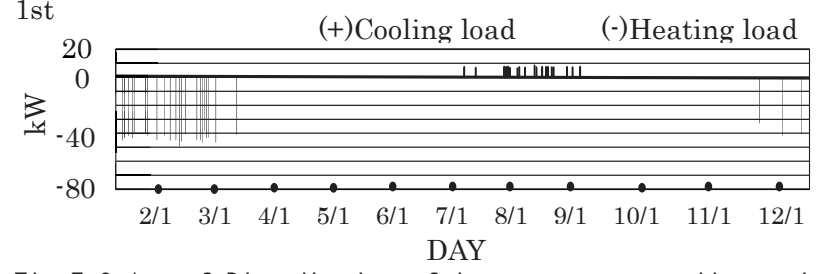

Fig. 7-3 1st of Distribution of instantaneous cooling and heating loads in Tokyo

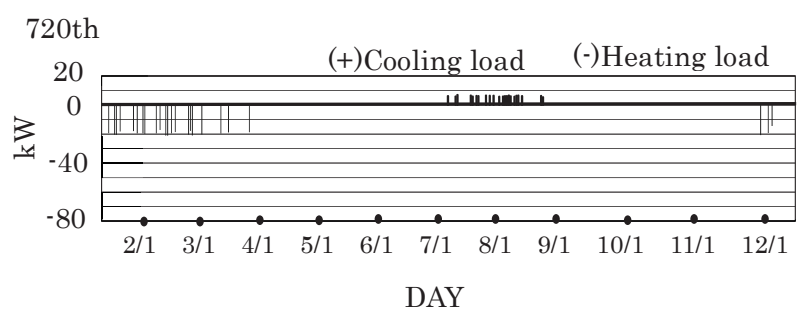

Fig. 7-4 $720^{\text {th }}$ of Distribution of instantaneous cooling and heating loads in Tokyo

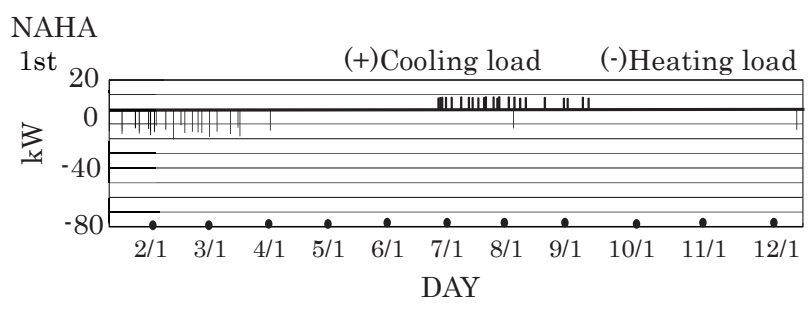

Fig. 7-5 1st of Distribution of instantaneous cooling and heating loads in Naha

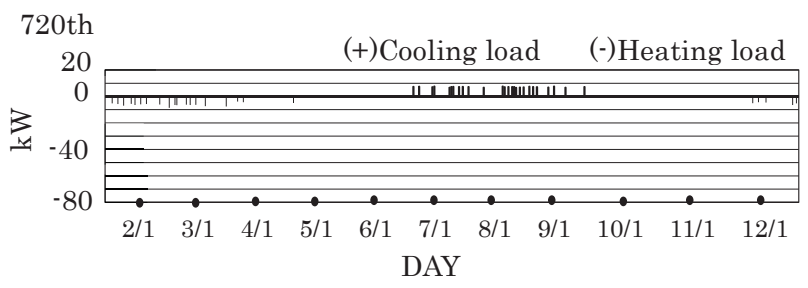

Fig. 7-6 $720^{\text {th }}$ of Distribution of instantaneous cooling and heating loads in Naha

(6) 瞬時冷暖房負荷経年変化

代表的な 3 地点（札幌, 東京, 那覇）の瞬時冷暖房負荷（1 位お よび 720 位)，Fig. 8-1，9-1，10-1 に示す。 瞬時暖房負荷の大き い順は 1 位, 720 位とも断熱水準 1, 水準 2 , 水準 3 の順になって いる。差の大きさは札幌, 東京, 那覇の順である。変動形状は 1 位 および 720 位は比較的よく似ている。瞬時冷房負荷の変動は, 札 幌，東京，那覇とも断熱水準による差はあまり見られない。

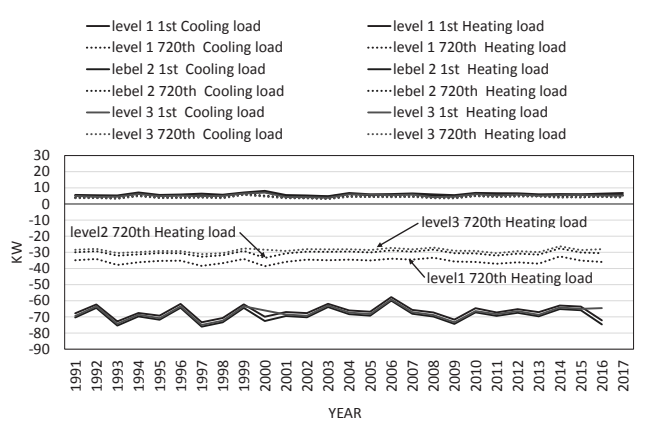

Fig. 8-1 Instantaneous cooling and heating loads 1st and 720th (from 1991 to 2017 in Sapporo)

札幌の夏季, 冬季の気温, エンタルピーの 1 位を Fig. 8-2 に示す。 最低気温 1 位, 最低エンタルピー 1 位の経年上昇に伴い, 暖房のピ ーク負荷が下降するのが確認できる。 


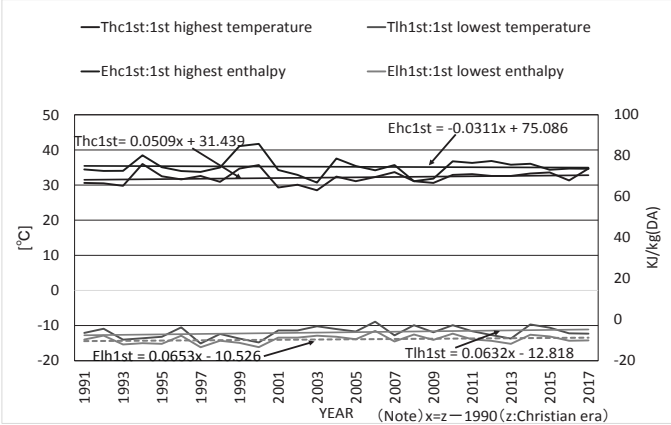

Fig. 8-2 The highest, lowest temperature and highest, lowest enthalpy (from 1991 to 2017 in Sapporo)

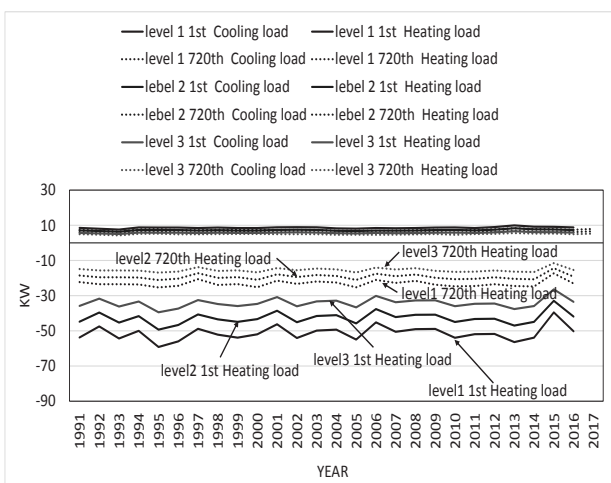

Fig. 9-1 Instantaneous cooling and heating loads

1st and 720th (from 1991 to 2017 in Tokyo)

東京の夏季, 冬季の気温, エンタルピーの 1 位を Fig. 9-2 に示す。 最高気温 1 位, 最高エンタルピー 1 位の経年上昇と冷房ピーク負荷 の上昇傾向は一致している。

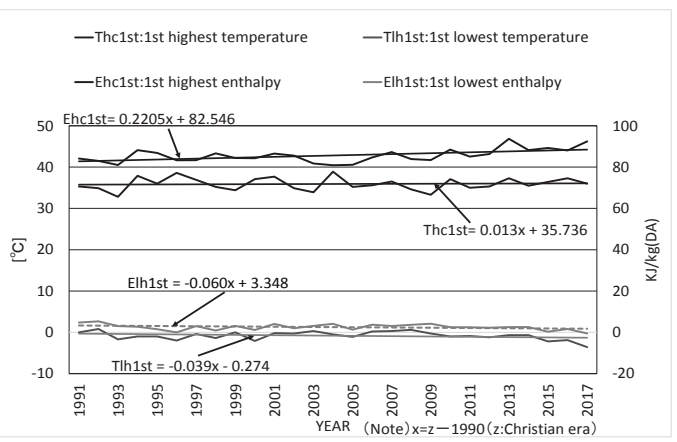

Fig. 9-2 The highest, lowest temperature and highest, lowest Enthalpy (from 1991 to 2017 in Tokyo)

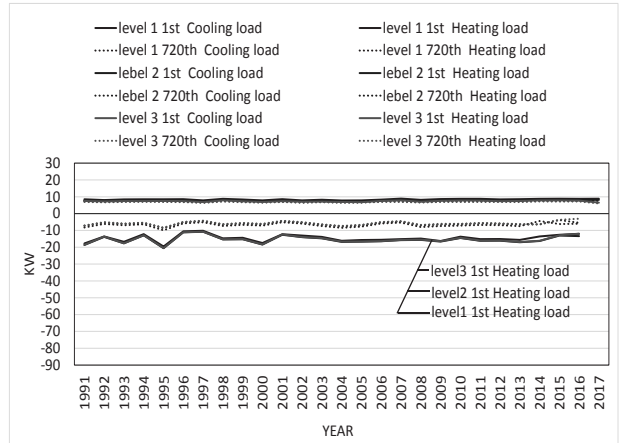

Fig. 10-1 Instantaneous cooling and heating loads 1st and 720th (from 1991 to 2017 in Naha)
那覇の夏季, 冬季の気温, エンタルピーの 1 位を Fig. 10-2 に 示す。最高気温 1 位, 最高エンタルピー 1 位の経年上昇と冷房 ピーク負荷の上昇傾向は一致している。

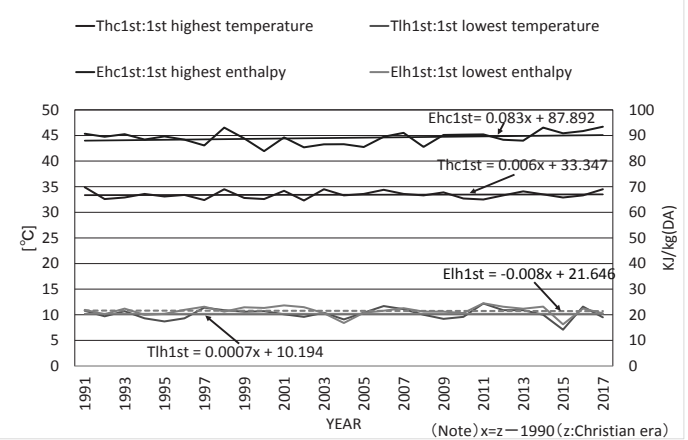

Fig. 10-2 The highest, lowest temperature and highest, lowest enthalpy (from 1991 to 2017 in Naha)

\section{2 年間冷暖房負荷の解析}

（1）部位別冷暖房負荷

2016 年冬季， 2017 年夏季の東京断熱水準 1，2，3 の部位別冷暖房 負荷をFig. 11，12 に示寸。冷房に占める割合は開口部，内部発熱， 隙間風の順になる。暖房に占める割合は隙間風，外壁，開口部の順 になり，隙間風防止，外壁の断熱化，開口部のガラス複層化が省工 ネルギーに効果があることがわかる。

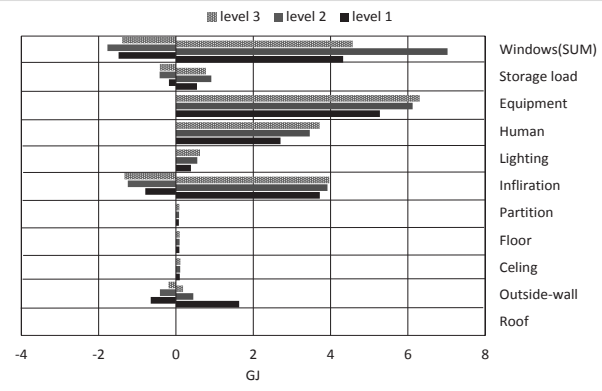

Fig. 11 Each element cooling loads (2017 cooling season in Tokyo)

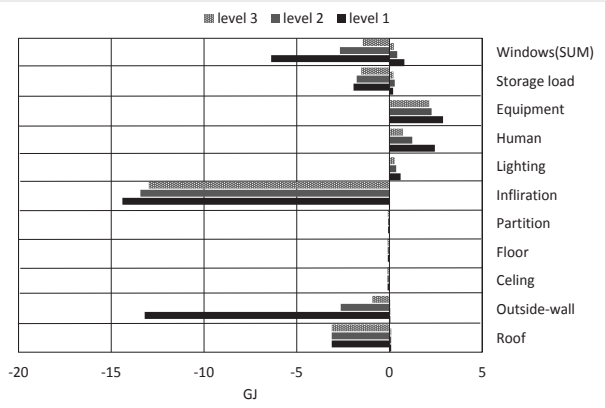

Fig. 12 Each element heating loads (2016 heating season in Tokyo)

(2) 日積算冷暖房負荷

東京の 3 シーズンの日別冷暖房負荷を Fig. 13 に示す。暖房負荷変 動は激しいのに対し，冷房負荷変動は比較的小さい。年間暖房負荷 は年間冷房負荷の約 1.25 倍である。 


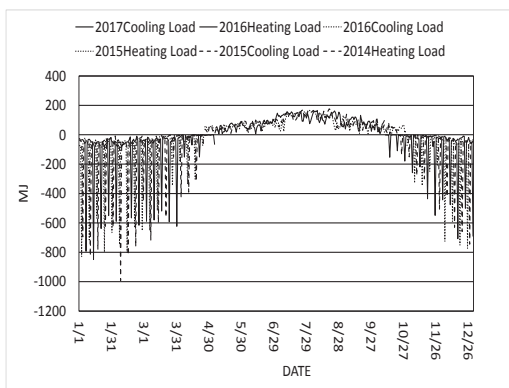

Fig. 13 Yearly cooling and heating loads

(3 seasons in Tokyo)

(3) 断熱水準 3 種類の年間冷暖房負荷の推移

建物の断熱水準を 3 種類想定し, 代表的な 3 地点札幌, 東京, 那覇の年間冷暖房負荷, また, 水準 2 の潜熱負荷を Fig. 14-1，151，16-1 に示す。3 地点のデグリーデイ, エンタルピーデイを Fig. 14-2，15-2，16-2 に示す。

なお暖房デグリーデイは $18^{\circ} \mathrm{C}$ 基準(表記 Dh18), 暖房エンタルピ 一デイは $30 \mathrm{~kJ} / \mathrm{kg}$ (DA) 基準(表記 $\mathrm{Eh} 30$ ), 冷房デグリーデイは $26^{\circ} \mathrm{C}$ 基準(表記 Dc26), 冷房エンタルピーデイは $60 \mathrm{~kJ} / \mathrm{kg}$ (DA) 基準(表 記 Ec60)である。

1) 札幌の冷暖房負荷特性

札幌は断熱基準の違いが年間暖房負荷に端的に現れ, 断熱の必要 性がある。水準 2 の暖房負荷は経年変化でやや減少する傾向にあ る。また暖房全熱負荷に対する潜熱割合は 1 2 割程度である。

札幌の同期間の冷房デグリーデイ, 冷房エンタルピーデイは増加 傾向にあり, 年間冷房負荷の増加と一致している。暖房デグリーデ イ, 暖房エンタルピーデイは減少傾向にある。年間暖房負荷は経年 で減少しており, デグリーデイ, エンタルピーデイが減少している のと傾向が一致している。

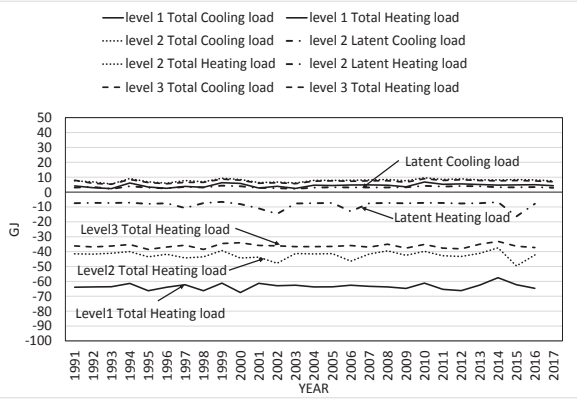

Fig. 14-1 Yearly cooling and heating loads (from 1991 to 2017 in Sapporo)

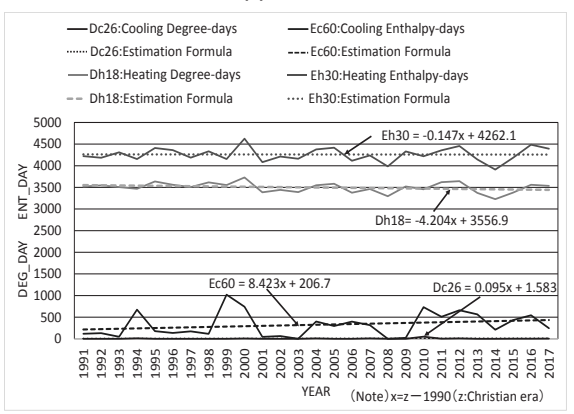

Fig. 14-2 Yearly degree-days and enthalpy-days (from 1991 to 2017 in Sapporo)

\section{2) 東京の冷暖房負荷特性}

東京の年間冷房負荷と年間暖房負荷はほぼ 1 対 1 である。

断熱水準の違いは年間暖房負荷に表れ，水準 1 と水準 2 の差が明確 に表れている。水準 2 と水準 3 の暖房負荷の差はあまり見られない。 水準 2 の潜熱負荷の暖房全熱に占める割合は 2 割程度である。

年間冷房負荷は断熱水準の違いによる差は顕著に表れない。潜熱負 荷は全熱冷房負荷の約 4 割である。

東京の同期間のデグリーデイ,エンタルピーデイはいずれも経年変 化で増加しているが，冷房エンタルピーの増加が大きい。年間冷房 負荷の経年変化は増加しており, 年間デグリーデイ, エンタルピー デイの増加と一致している。年間暖房負荷は増加しておりデグリー デイ, エンタルピーデイの増加傾向と一致している。

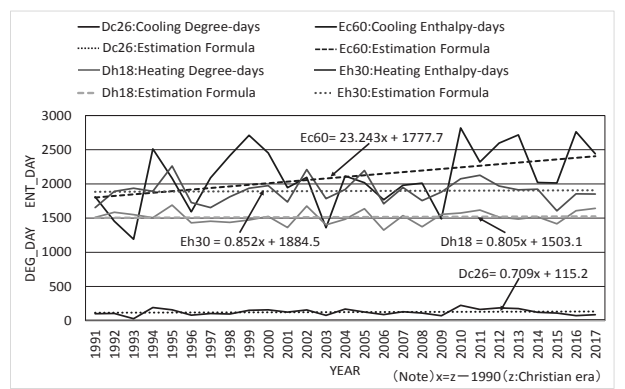

Fig. 15-1 Yearly cooling and heating loads (from 1991 to 2017 in Tokyo)

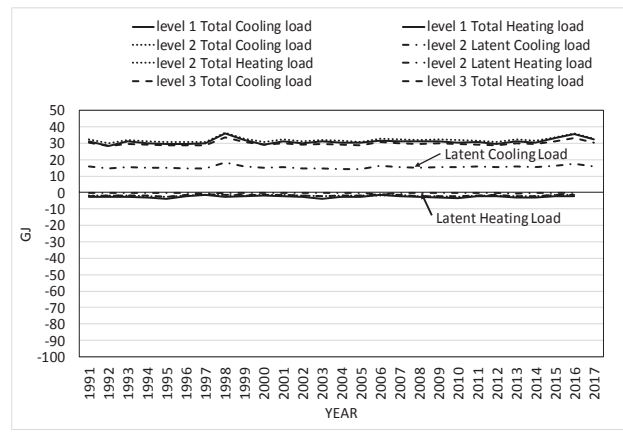

Fig. 15-2 Yearly degree-days and enthalpy-days (from 1991 to 2017 in Tokyo)

3) 那覇の冷暖房負荷特性

那覇の年間冷房負荷は $30 \mathrm{GJ}$ 程度で東京の約 2 倍程度である。断 熱水準の違いは明確には表れていない。年間潜熱冷房負荷の割合 は年間全熱冷房負荷の約 5 割程度である。年間暖房負荷は $2 \mathrm{GJ}$ 程 度で非常に小さい。

那覇の同期間の冷房デグリーデイ, 冷房エンタルピーデイが増加 し年間冷房負荷が増加する傾向は一致している。

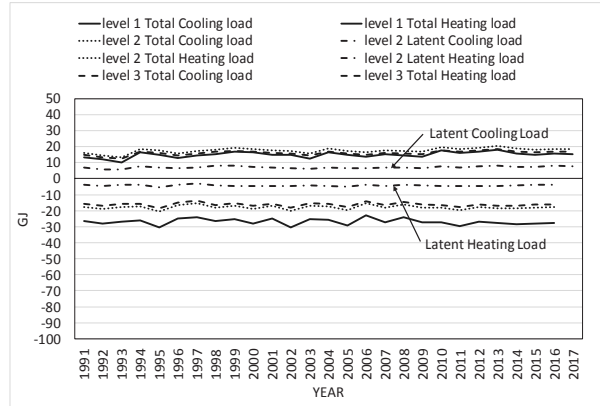

Fig. 16-1 Yearly cooling and heating loads (from 1991 to 2017 in Naha) 
Table4 Comparison of instantaneous cooling and heating load approximation expressions of Sapporo, Tokyo, Naha

\begin{tabular}{|c|c|c|c|c|c|c|c|c|c|c|c|c|}
\hline Point & Insulation & Rank & Load & Linear expression & $\begin{array}{l}\text { Residual } \\
\text { dispersion }\end{array}$ & index & \begin{tabular}{|l||}
$\begin{array}{l}\text { Residual } \\
\text { dispersion }\end{array}$ \\
\end{tabular} & Logarithm & $\begin{array}{c}\text { Residual } \\
\text { dispersion }\end{array}$ & equation & $\begin{array}{l}\text { Residual } \\
\text { dispersion }\end{array}$ & $\begin{array}{l}\text { Increase and } \\
\text { decrease (Yyearly kW) }\end{array}$ \\
\hline \multirow{6}{*}{ SAPPORO } & \multirow{2}{*}{ Levell } & \multirow{2}{*}{ 7200th } & Cooling Load & $y=0.0237 x+4.1542$ & & $y=4.0944 e^{\text {exastin }}$ & & $y=0.2430 \mathrm{ln}(x)+3.9030$ & & $=-0.0010 x^{2}+0.052 x+4.0193$ & 0.438 & \\
\hline & & & Heating Load & $y=0.0390 x-36.001$ & 2.300 & $y=35.976 e^{-0.0 / x}$ & 2.300 & $y=0.2114 \ln (x)-35.984$ & 2.392 & $y=0.0005 x^{2}+0.0262 x-35.943$ & 2.299[ & $0.0401(-)$ \\
\hline & \multirow{2}{*}{ Level2 } & \multirow{2}{*}{ 720th } & Cooling Load & $y=0.0180 x+4.0410$ & 0.281 & $y=3.9968 \mathrm{e}^{\text {expate }}$ & 0.282 & $y=0.1903 \ln (x)+3.8386$ & 0.287 & $y=-0.0008 x^{2}+0.0404 x+3.9328$ & 0.279 & $0.0183(+)$ \\
\hline & & & Heating Load & $y=0.0386 x-30$. & 1.783 & $y=30.899 \mathrm{e}$ & 1.783 & $y=0.2426 \ln (x)-30.971$ & 1.860 & $y=-0.0007 x^{2}+0.0563 x-31.004$ & 1.781 [ & $0382(-)$ \\
\hline & \multirow[b]{4}{*}{ Levell } & \multirow{2}{*}{ 720th } & Cooling Load & $y=0.0208 x+3.7622$ & 0.366 & $y=3.7095 e^{\text {exsifit }}$ & 0.366 & $y=0.2088 \ln (x)+3.5565$ & 0.381 & $y=-0.0006 x^{2}+0.0363 x+3.6887$ & 0.367 & \\
\hline & & & Heating Load & $y=0.0385 x-29.298$ & 1.467 & $y=29.282 e^{-0.00 x}$ & 1.467 & $y=0.2554 \ln (x)-29.385$ & 1.520 & $y=-0.0017 x^{2}+0.0827 x-29.492$ & 1.460 & $368(-)$ \\
\hline \multirow{6}{*}{ TOKYO } & & & & $y=0.0$ & 0116 & $y=6.4$ & & $y=0.16$ & & $y=0.0$ & & \\
\hline & & T2uth & & & 3.082 & $y=22$ & 82 & $y=0.1694$ & 3.147 & $y=0.0014 x^{2}-0.0$ & 3.077 . & $(-)$ \\
\hline & & \multirow{2}{*}{ 720th } & Cooling Load & $y=0.0154 x+5.9800$ & 0.101 & $y=5.9754 e^{\text {expratin }}$ & 0.106 & $y=0.1189 \ln (x)+5.9109$ & 0.112 & $y=0.0016 x^{2}-0.0283 x+6.1911$ & 0.099 & $\left.0.01511^{+}\right)$ \\
\hline & & & Heating Load & $y=0.02$ & 55 & $y=19$ & 2.256 & $y=0$ & 11 & $y=0$. & 324 & $8(-)$ \\
\hline & & & Cooling Load & $y=0.01$ & 0.091 & $y=5.7$ & 0.091 & $y=0.12$ & 0.098 & $y=0.0$ & 0.082 & (t) \\
\hline & Levels & ILUn & & & & & & $y=0.09$ & & & & \\
\hline \multirow{6}{*}{ NAHA } & \multirow{2}{*}{ Levell } & \multirow[b]{2}{*}{ 720th } & & & & & $0.071 \times x=2 x$ & & & & 0.054 & \\
\hline & & & Heati & $y=0.02$ & 1.495 & $y=7.0016 e^{-0.0064}$ & 1.495 & $y=0.2566 \ln (x)-7.3742$ & 1.501 & $y=0.0009 x^{2}+1$ & 1.493 & $0.0260(-)$ \\
\hline & \multirow{2}{*}{ Level2 } & \multirow{2}{*}{ 720th } & $\begin{array}{ll}\text { Cooling Load } \\
\end{array}$ & $y=0.0135 x+6.9659$ & 0.053 & $y=6.9648 e^{c 0018 x}$ & 0.063 & $y=0.0662 \ln (x)+6.9970$ & 0.072 & $=0.0026 x^{2}-0$ & 0.043 & $0.0131(++)$ \\
\hline & & & Heating Load & $y=0.0$ & 1.188 & $y=6$ & 1.188 & & .183 & $y=0.0010 x^{2}-0.0$ & 1.185 ] & $0.0179(-)$ \\
\hline & Level3 & $1 / 20$ & & & 0.05 & & 1.064 & & 0.061 & & 0.055 & \\
\hline & & & & 5.9849 & 1.167 & $y=$ & 1.167 y & $y=0.1765 \ln (x)-6.1883$ & 1.15 & $y=0.0007 x^{2}-0.0012 x-5.9080$ & 166 & \\
\hline
\end{tabular}

(Note) $\mathrm{x}=\mathrm{z}-1990 （ \mathrm{z}$ :Christian era) The increase value is estimated 2017 for on year

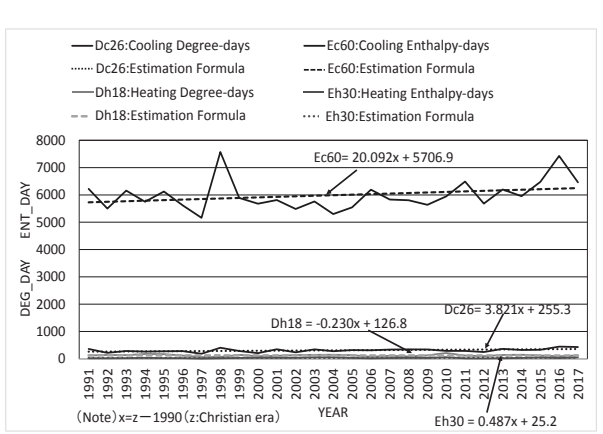

Fig. 16-2 Year ly degree-days and enthalpy-days

(from 1991 to 2017 in Naha)

\section{3 冷暖房負荷の近未来推定}

1991 年〜2017 年までの気象データから熱負荷を算出しその経年変 化および推定式の検定を行い，選定した式による数年後の年当り熱 負荷の増減を予測する。

（1）札幌, 東京, 那覇の瞬時冷暖房負荷近似式

瞬時冷暖房負荷の時系列変動を 1 次式, 指数式, 対数式, 2 次式を 適用し残差分散の一番小さなものを推定式として採用した。

黒塗り部は採用した式である。近似式の比較をTable4 に示す。

\section{(2) 瞬時冷暖房負荷の経年変化}

各地点の選定された推定式による水準 2 の瞬時冷暖房負荷 720 位の経年による増減を Tab1e5 に示す。

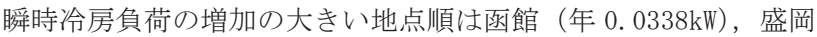
(年 $0.0304 \mathrm{~kW}$ ), 石垣島 (年 $0.0291 \mathrm{~kW}$ ), 青森 (年 $0.0290 \mathrm{~kW}$ ), 秋 田（年 $0.0280 \mathrm{kw}$ の順である。

減少しているのは 1 地点甲府（年 $0.0061 \mathrm{kW）のみである。}$ 瞬時暖房負荷が減少している地点は大きい順で, 石垣島（年 $0.0663 \mathrm{~kW}$ ), 宮古島 (年 $0.0456 \mathrm{~kW}$ ), 青森 (年 $0.0429 \mathrm{~kW}$ ), 名瀬 (年 $0.0424 \mathrm{~kW}$ ), 網走 (年 $0.0390 \mathrm{~kW})$ の順である。

逆に瞬時暖房負荷が増加している地点は大きい順で，長崎（年 $0.0632 \mathrm{~kW}$ ), 広島 (年 $0.0212 \mathrm{~kW})$, 松山 (年 $0.0206 \mathrm{~kW})$, 熊本 (年 $0.0156 \mathrm{~kW})$, 大阪 (年 $0.0084 \mathrm{~kW})$ の順である。
Table5 Increase / decrease of instantaneous cooling and heating load by selected approximate expression at each point (Level2)

\begin{tabular}{|c|c|c|c|}
\hline \begin{tabular}{|} 
Region \\
classification
\end{tabular} & Point & Load & $\begin{array}{l}\text { Increase and } \\
\text { decrease(yearly kW) }\end{array}$ \\
\hline \multirow{6}{*}{1} & \multirow{2}{*}{ WAKKANAI } & Cooling load & $0.0220(+)$ \\
\hline & & Heating load & $0.0094(-)$ \\
\hline & \multirow{2}{*}{ ABASHIRI } & Cooling load & $0.0163(+)$ \\
\hline & & Heating load & $0.0390(-)$ \\
\hline & \multirow{2}{*}{ ASAHIKAWA } & Cooling load & $0.0209(+)$ \\
\hline & & Heating load & $0.0369(-)$ \\
\hline \multirow{4}{*}{2} & \multirow{2}{*}{ SAPPORO } & Cooling load & $0.0183(+)$ \\
\hline & & Heating load & $0.0382(-)$ \\
\hline & \multirow{2}{*}{ HAKODATE } & Cooling load & $0.0338(+)$ \\
\hline & & Heating load & $0.0086(-)$ \\
\hline \multirow{6}{*}{3} & \multirow{2}{*}{ AOMORI } & Cooling load & $0.0290(+)$ \\
\hline & & Heating load & $0.0429(-)$ \\
\hline & \multirow{2}{*}{ MORIOKA } & Cooling load & $0.0304(+)$ \\
\hline & & Heating load & $0.0189(-)$ \\
\hline & \multirow{2}{*}{ AKITA } & Cooling load & $0.0280(+)$ \\
\hline & & Heating load & $0.0175(-)$ \\
\hline \multirow[b]{2}{*}{4} & \multirow{2}{*}{ SENDAI } & Cooling load & $0.0240(+)$ \\
\hline & & Heating load & $0.0077(+)$ \\
\hline \multirow{4}{*}{5} & \multirow{2}{*}{ NIIGATA } & Cooling load & $0.0159(+)$ \\
\hline & & Heating load & $0.0179(-)$ \\
\hline & \multirow{2}{*}{ KOFU } & Cooling load & $0.0061(-)$ \\
\hline & & Heating load & $0.0079(+)$ \\
\hline \multirow{24}{*}{6} & $\mathrm{CHOSHI}$ & Cooling load & $0.0241(+)$ \\
\hline & CHOSHI & Heating load & $0.0179(-)$ \\
\hline & TOYY & Cooling load & $0.0151(+)$ \\
\hline & TOKYO & Heating load & $0.0239(-)$ \\
\hline & NAGOYA & Cooling load & $0.0055(+)$ \\
\hline & NAGOYA & Heating load & $0.0141(-)$ \\
\hline & & Cooling load & $0.0066(+)$ \\
\hline & OSAKA & Heating load & $0.0084(+)$ \\
\hline & & Cooling load & $0.0102(+)$ \\
\hline & HIROSHIMA & Heating load & $0.0212(+)$ \\
\hline & & Cooling load & $0.0178(+)$ \\
\hline & SHIMONOSEKI & Heating load & $0.0045(+)$ \\
\hline & & Cooling load & $0.0042(+)$ \\
\hline & TAKAMATSU & Heating load & $0.0264(-)$ \\
\hline & & Cooling load & $0.0169(+)$ \\
\hline & MATSUYAMA & Heating load & $0.0206(+)$ \\
\hline & & Cooling load & $0.0231(+)$ \\
\hline & FUKUOKA & Heating load & $0.0017(+)$ \\
\hline & & Cooling load & $0.0136(+)$ \\
\hline & NAGASAKI & Heating load & $0.0632(+)$ \\
\hline & КНМАМОТО & Cooling load & $0.0139(+)$ \\
\hline & КUMAMOTO & Heating load & $0.0156(+)$ \\
\hline & & Cooling load & $0.0076(+)$ \\
\hline & OITA & Heating load & $0.0088(-)$ \\
\hline & MIYAZAKI & Cooling load & $0.0056(+)$ \\
\hline 7 & & Heating load & $0.0229(-)$ \\
\hline 1 & KAGOSHIMA & Cooling load & $0.0219(+)$ \\
\hline & KAGOSHIMA & Heating load & $0.0377(-)$ \\
\hline & & Cooling load & $0.0078(+)$ \\
\hline & NAZE & Heating load & $0.0424(-)$ \\
\hline & & Cooling load & $0.0131(+)$ \\
\hline & NAHA & Heating load & $0.0179(-)$ \\
\hline 8 & & Cooling load & $0.0291(+)$ \\
\hline 8 & ISHIGAKIJIMA & Heating load & $0.0663(-)$ \\
\hline & MIYAKO JIMA & Cooling load & $0.0163(+)$ \\
\hline & MIYAKOJIMA & Heating load & $0.0456(-)$ \\
\hline & $\mathrm{CHICHIJIMA}$ & Cooling load & $0.0093(+)$ \\
\hline & CHICHIJIMA & Heating load & $0.0075(-)$ \\
\hline
\end{tabular}

(Note) The increase value is estimated 2017 for one year 
(3) 年間冷暖房負荷の時系列近似式

年間冷暖房負荷の時系列変動を 1 次式, 指数式, 対数式, 2 次式

を適用し残差分散の一番小さなものを推定式として採用した。

Table6 Comparison of yearly cooling and heating load approximation formula of Sapporo, Tokyo, Naha

\begin{tabular}{|c|c|c|c|c|c|c|c|c|c|c|c|}
\hline & & & Linear expression & $\begin{array}{c}\text { Residual } \\
\text { dispersion }\end{array}$ & index & $\begin{array}{c}\text { Residual } \\
\text { dispersion }\end{array}$ & Logarithm & $\begin{array}{c}\text { Residual } \\
\text { dispersion }\end{array}$ & Quadratic equation & \begin{tabular}{|c} 
Residual \\
dispersion
\end{tabular} & \begin{tabular}{|l} 
Increase and \\
decrease(Yearly \\
GJ)
\end{tabular} \\
\hline \multirow{6}{*}{ SAPPORO } & \multirow{2}{*}{ level1 } & CoolingLoad & $y=0.0622 x+3.5062$ & 1.257 & $y=3.3221 e^{0.0168 x}$ & 1.263 & $y=0.5441 \ln (x)+3.0756$ & 1.272 & $y=-0.0014 x 2+0.1014 x+3.316$ & 1.250 & $0.0617(+)$ \\
\hline & & \begin{tabular}{|l} 
Heating Load \\
\end{tabular} & $y=0.0447 x-63.998$ & 4.340 & $y=63.989 e^{-7 E-04 x}$ & 4.340 & $y=0.3285 \ln (x)-64.168$ & 4.578 & $y=0.0028 x^{2}-0.0308 x-63.645$ & 4.319 & $0.0451(-)$ \\
\hline & \multirow{2}{*}{ level2 } & CoolingLoad & $y=0.0591 x+6.9204$ & 0.904 & $y=6.8393 e^{0.0082 x}$ & 0.906 & $y=0.5061 \ln (x)+6.5376$ & 0.925 & $y=-0.0012 x^{2}+0.0925 x+6.759$ & 0.899 & $0.0602(+)$ \\
\hline & & \begin{tabular}{|l} 
Heating Load \\
\end{tabular} & $y=0.0218 x-41.597$ & 5.311 & $y=42.122 e^{0.0004 x}$ & 5.313 & $y=-0.352 \ln (x)-41.594$ & 5.665 & $y=0.0044 x^{2}-0.1414 x-41.564$ & 5.358 & $0.0218(-)$ \\
\hline & \multirow{2}{*}{ level3 } & CoolingLoad & $y=0.0591 x+6.3962$ & 0.918 & $y=6.3157 \mathrm{e}^{0.0089 x}$ & 0.918 & $y=0.3909 \ln (x)+6.2581$ & 0.848 & $y=0.0025 x^{2}-0.0058 x+6.6884$ & 0.903 & $0.0586(+)$ \\
\hline & & Heating Load & $y=0.0141 x-36.455$ & 1.825 & $y=36.443 e^{-4 E-04 x}$ & 1.825 & $y=0.1303 \ln (x)-36.571$ & 1.893 & $y=-0.0009 x^{2}+0.0392 x-36.572$ & 1.823 & $0.0138(-)$ \\
\hline \multirow{6}{*}{ TOKYO } & \multirow{2}{*}{ level1 } & CoolingLoad & $y=0.1082 x+13.454$ & 2.522 & $y=13.33 e^{0.0078 x}$ & 2.538 & $y=1.1116 \ln (x)+12.311$ & 2.361 & $y=-0.0059 x^{2}+0.2724 x+12.661$ & 2.414 & $0.1121(+)$ \\
\hline & & Heating Load & $y=-0.0385 x-26.381$ & 3.722 & $y=26.308 e^{0.0015 x}$ & 3.721 & $y=-0.162 \ln (x)-26.519$ & 3.963 & $y=-0.0091 x^{2}+0.2059 x-27.522$ & 3.514 & $0.0381(+)$ \\
\hline & \multirow{2}{*}{ level2 } & \begin{tabular}{|l} 
CoolingLoad \\
\end{tabular} & $y=0.1187 x+15.919$ & 1.674 & $y=15.863 e^{0.0071 x}$ & 1.685 & $y=1.1769 \ln (x)+14.767$ & 1.529 & $y=-0.0042 x^{2}+0.235 x+15.357$ & 1.767 & $0.1142(+)$ \\
\hline & & Heating Load & $y=-0.0177 x-17.624$ & 1.851 & $y=17.566 e^{0.0011 x}$ & 1.851 & $y=-0.077 \ln (x)-17.681$ & 1.962 & $y=-0.0035 x^{2}+0.0757 x-18.06$ & 1.777 & $0.0183(+)$ \\
\hline & \multirow{2}{*}{ level3 } & \begin{tabular}{|l} 
CoolingLoad \\
\end{tabular} & $y=0.095 x+14.724$ & 1.249 & $y=14.676 e^{0.0062 x}$ & 1.254 & $y=0.9305 \ln (x)+13.83$ & 1.156 & $y=-0.0027 x^{2}+0.1702 x+14.361$ & 1.226 & $0.0967(+)$ \\
\hline & & \begin{tabular}{|l} 
Heating Load \\
\end{tabular} & $y=-0.0138 x-16.051$ & 1.391 & $y=15.995 \mathrm{e}^{0.0009 x}$ & 1.391 & $y=-0.067 \ln (x)-16.079$ & 1.459 & $y=-0.0021 x^{2}+0.0436 x-16.319$ & 1.384 & $0.0143(+)$ \\
\hline \multirow{6}{*}{ NAHA } & \multirow{2}{*}{ level1 } & \begin{tabular}{|l|} 
CoolingLoad \\
\end{tabular} & $y=0.0757 x+29.919$ & 2.590 & $y=29.9 e^{0.0024 x}$ & 2.587 & $y=0.5997 \ln (x)+29.545$ & 2.623 & $y=0.005 x^{2}-0.0645 x+30.597$ & 2.512 & $0.0769(+)$ \\
\hline & & Heating Load & $y=0.0004 x-2.6057$ & 0.372 & $y=2.5294 e^{5 E-05 x}$ & 0.372 & $y=0.0398 \ln (x)-2.6945$ & 0.385 & $y=-0.0009 x^{2}+0.0247 x-2.719$ & 0.370 & $0.0003(-)$ \\
\hline & \multirow{2}{*}{ level2 } & \begin{tabular}{|l} 
CoolingLoad \\
\end{tabular} & $y=0.0613 x+31.158$ & 1.950 & $y=31.139 e^{0.0019 x}$ & 1.948 & $y=0.498 \ln (x)+30.826$ & 1.974 & $y=0.0033 x^{2}-0.0325 x+31.612$ & 1.915 & $0.0608(+)$ \\
\hline & & Heating Load & $y=-0.0005 x-1.9041$ & 0.143 & $y=1.8744 e^{0.0001 x}$ & 0.143 & $y=0.0123 \ln (x)-1.9414$ & 0.151 & $y=-0.0003 x^{2}+0.0082 x-1.9489$ & 0.144 & $0.0006(+)$ \\
\hline & \multirow{2}{*}{ level3 } & CoolingLoad & $y=0.0149 x+29.495$ & 1.618 & $y=29.458 e^{0.0006 x}$ & 1.618 & $y=0.0935 \ln (x)+29.447$ & 1.590 & $y=-0.005 x^{2}+0.1099 x+29.178$ & 1.603 & $0.0152(+)$ \\
\hline & & Heating Load & $y=0.0047 x-1.8263$ & 0.194 & $y=1.7646 e^{-0.002 x}$ & 0.194 & $y=0.1033 \ln (x)-2.0056$ & 0.185 & $y=-0.0018 x^{2}+0.053 x-2.0515$ & 0.186 & $0.0049(-)$ \\
\hline
\end{tabular}

(Note) $\mathrm{x}=\mathrm{z}-1990(\mathrm{z}$ :Christian era) The increase value is estimated 2017 for one year

札幌，東京，那覇の近似式の比較を Table6 に示寸。Table6 の黒塗 り部は採用した式である。

(4) 年間冷暖房負荷の経年変化

各地点の選定された推定式による水準 2 の年間冷暖房負荷の経 年による増減を Table7 に示す。

年間冷房負荷は全ての地点で増加している。増加の大きい地点順 は福岡 (年 $0.8380 \mathrm{GJ}$ ), 長崎 (年 $0.1415 \mathrm{GJ}$ ), 石垣島 (年 $0.1397 \mathrm{GJ}$ ), 銚子（年 $0.1326 \mathrm{GJ}$ ), 東京（年 $0.1142 \mathrm{GJ}$ ）の順である。 年間暖房負荷が減少している地点は大きい順で, 仙台（年 0.1020GJ), 稚内 (年 $0.0976 \mathrm{GJ})$, 網走 (年 $0.0915 \mathrm{GJ})$, 鹿児島 (年 $0.0566 \mathrm{GJ})$ ，盛岡（年 $0.0433 \mathrm{GJ} ）$ の順である。

逆に年間暖房負荷が増加している地点は大きい順で長崎（年 $0.0310 \mathrm{GJ}$ ), 札幌 (年 $0.0218 \mathrm{GJ}$ ), 東京 (年 $0.0183 \mathrm{GJ}$ ), 宮崎 (年 0.0176GJ）の順である。

\section{6. まとめ}

1）瞬時冷房負荷は 1 地点（甲府）を除き，29 地点で増加している。 増加の大きな地点は函館の (年 $0.0338 \mathrm{~kW}$ ) で次いで盛岡, 石垣島, 青森, 秋田の順である。甲府は減少しているが(年 $0.0061 \mathrm{~kW}$ )で非 常に小さい。

2) 瞬時暖房負荷は経年変化で増加している地点と減少している地点 がある。増加している地点は冬季の極寒期の外気温度の変動が年 によって異なり, 経年変化で単調に上昇していないためである。 減少の大きな地点は石垣島の (年 $0.0663 \mathrm{~kW})$ で, 次いで宮古島, 青 森の順で, 増加の大きな地点は長崎の (年 $0.0632 \mathrm{~kW})$ で, 次いで広 島，松山の順である。

3) 年間冷房負荷は都市およびその他の地点でいずれも増加している。 増加の大きい地点は福岡の (年 $0.838 \mathrm{GJ}$ ) で次いで長崎, 石垣島, 銚子，東京の順である。

4) 年間暖房負荷は経年変化で減少している地点が多いが増加してい る地点もある。暖房負荷に大きく影響する外気温度が経年変化で
Table7 Increase and decrease of yearly cooling and heating load according to selected approximate formula at each point (Level2)

\begin{tabular}{|c|c|c|c|}
\hline \begin{tabular}{|l|}
$\begin{array}{l}\text { Region } \\
\text { classification }\end{array}$ \\
\end{tabular} & point & load & $\begin{array}{l}\text { Increase and } \\
\text { decrease(yearly GJ }\end{array}$ \\
\hline \multirow[t]{6}{*}{ (2) } & \multirow{2}{*}{ WAKKANAI } & \begin{tabular}{|l} 
Cooling load \\
\end{tabular} & $0.0530(+)$ \\
\hline & & \begin{tabular}{|l} 
Heating load \\
\end{tabular} & $0.0976(-)$ \\
\hline & \multirow{2}{*}{ ABASHIRI } & Cooling load & $0.0475(+)$ \\
\hline & & \begin{tabular}{|l} 
Heating load \\
\end{tabular} & $0.0915(-)$ \\
\hline & \multirow{2}{*}{ ASAHIKAWA } & \begin{tabular}{|l} 
Cooling load \\
\end{tabular} & $0.0516(+)$ \\
\hline & & \begin{tabular}{|l} 
Heating load \\
\end{tabular} & $0.0027(-)$ \\
\hline \multirow{4}{*}{2} & \multirow{2}{*}{ SAPPORO } & \begin{tabular}{|l|} 
Cooling load \\
\end{tabular} & $0.0602(+)$ \\
\hline & & \begin{tabular}{|l|} 
Heating load \\
\end{tabular} & $0.0232(+)$ \\
\hline & \multirow{2}{*}{ HAKODATE } & Cooling load & $0.0791(+)$ \\
\hline & & \begin{tabular}{|l} 
Heating load \\
\end{tabular} & $0.0243(-)$ \\
\hline \multirow{6}{*}{3} & \multirow{2}{*}{ AOMORI } & \begin{tabular}{|l|} 
Cooling load \\
\end{tabular} & $0.0721(+)$ \\
\hline & & \begin{tabular}{|l|l|l} 
Heating load \\
\end{tabular} & $0.0402(-)$ \\
\hline & \multirow{2}{*}{ MORIOKA } & \begin{tabular}{|l} 
Cooling load \\
\end{tabular} & $0.0976(+)$ \\
\hline & & \begin{tabular}{|l|} 
Heating load \\
\end{tabular} & $0.0433(-)$ \\
\hline & \multirow{2}{*}{ AKITA } & Cooling load & $0.0783(+)$ \\
\hline & & Heating load & $0.0267(-)$ \\
\hline \multirow{2}{*}{4} & \multirow{2}{*}{ SENDAI } & \begin{tabular}{|l} 
Cooling load \\
\end{tabular} & $0.1116(+)$ \\
\hline & & \begin{tabular}{|l} 
Heating load \\
\end{tabular} & $0.1020(-)$ \\
\hline \multirow{4}{*}{5} & \multirow{2}{*}{ NIIGATA } & \begin{tabular}{|l|} 
Cooling load \\
\end{tabular} & $0.0655(+)$ \\
\hline & & \begin{tabular}{|l|} 
Heating load \\
\end{tabular} & $0.0165(+)$ \\
\hline & \multirow{2}{*}{ KOFU } & \begin{tabular}{|l} 
Cooling load \\
\end{tabular} & $0.0803(+)$ \\
\hline & & \begin{tabular}{|l|} 
Heating load \\
\end{tabular} & $0.0082(-)$ \\
\hline \multirow{24}{*}{6} & $\mathrm{CHOSHI}$ & \begin{tabular}{|l} 
Cooling load \\
\end{tabular} & $0.1326(+)$ \\
\hline & CHOSHI & \begin{tabular}{|l} 
Heating load \\
\end{tabular} & $0.0065(+)$ \\
\hline & TOKYO & \begin{tabular}{|l} 
Cooling load \\
\end{tabular} & $0.1142(+)$ \\
\hline & TOKYO & \begin{tabular}{|l} 
Heating load \\
\end{tabular} & $0.0183(+)$ \\
\hline & NAGOYA & \begin{tabular}{|l|} 
Cooling load \\
\end{tabular} & $0.0746(+)$ \\
\hline & & \begin{tabular}{|l|} 
Heating load \\
\end{tabular} & $0.0150(+)$ \\
\hline & OSAKA & \begin{tabular}{|l|} 
Cooling load \\
\end{tabular} & $0.0730(+)$ \\
\hline & & \begin{tabular}{|l} 
Heating load \\
\end{tabular} & $0.0130(-)$ \\
\hline & HIROSHIMA & \begin{tabular}{|l} 
Cooling load \\
\end{tabular} & $0.0102(+)$ \\
\hline & & \begin{tabular}{|l|} 
Heating load \\
\end{tabular} & $0.0111(+)$ \\
\hline & & \begin{tabular}{|l} 
Cooling load \\
\end{tabular} & $0.0639(+)$ \\
\hline & SHIMONOSEKI & \begin{tabular}{|l} 
Heating load \\
\end{tabular} & $0.0283(-)$ \\
\hline & TAKAMATSU & \begin{tabular}{|l|} 
Cooling load \\
\end{tabular} & $0.0662(+)$ \\
\hline & TANAIMATSO & \begin{tabular}{|l} 
Heating load \\
\end{tabular} & $0.0309(-)$ \\
\hline & MATSUYAMA & \begin{tabular}{|l} 
Cooling load \\
\end{tabular} & $0.0525(+)$ \\
\hline & & \begin{tabular}{|l|} 
Heating load \\
\end{tabular} & $0.0027(+)$ \\
\hline & FUKUOKA & \begin{tabular}{|l|} 
Cooling load \\
\end{tabular} & $0.8380(+)$ \\
\hline & & Heating load & $0.0238(-)$ \\
\hline & NAGASAKI & Cooling load & $0.1415(+)$ \\
\hline & & \begin{tabular}{|l} 
Heating load \\
\end{tabular} & $0.0310(+)$ \\
\hline & КUМАМОТО & \begin{tabular}{|l|} 
Cooling load \\
\end{tabular} & $0.0139(+)$ \\
\hline & & \begin{tabular}{|l} 
Heating load \\
\end{tabular} & $0.0075(-)$ \\
\hline & & \begin{tabular}{|l|} 
Cooling load \\
\end{tabular} & $0.0785(+)$ \\
\hline & OITA & \begin{tabular}{|l|l} 
Heating load \\
\end{tabular} & $0.0186(-)$ \\
\hline & MIYAZAKI & \begin{tabular}{|l|} 
Cooling load \\
\end{tabular} & $0.0384(+)$ \\
\hline 7 & MIYAZAKI & \begin{tabular}{|l|l|l} 
Heating load \\
\end{tabular} & $0.0176(+)$ \\
\hline & KAGOSHIMA & \begin{tabular}{|l|} 
Cooling load \\
\end{tabular} & $0.0718(+)$ \\
\hline & KAGOSHIMA & \begin{tabular}{|l|l|l} 
Heating load \\
\end{tabular} & $0.0566(-)$ \\
\hline & NAZE & \begin{tabular}{|l|} 
Cooling load \\
Heating load
\end{tabular} & $\begin{array}{l}0.0451(+) \\
0.0170(-)\end{array}$ \\
\hline & NAHA & \begin{tabular}{|l|} 
Cooling load \\
\end{tabular} & $0.0608(+)$ \\
\hline & NAHA & \begin{tabular}{|l} 
Heating load \\
\end{tabular} & $0.0006(+)$ \\
\hline 8 & ISHIGAKIJIMA & \begin{tabular}{|l} 
Cooling load \\
\end{tabular} & $0.1397(+)$ \\
\hline & ISHIGAKIJIMA & \begin{tabular}{|l|} 
Heating load \\
\end{tabular} & $0.0085(-)$ \\
\hline & MIYAKO JIMA & Cooling load & $0.0759(+)$ \\
\hline & MIYAKO JIMA & Heating load & $0.0088(-)$ \\
\hline & CHICHIJIMA & Cooling load & $0.0490(+)$ \\
\hline & & Heating load & $0.0031(-)$ \\
\hline
\end{tabular}

(Note) The increase value is estimated 2017 for one year 
必ずしも上昇していないためである。

減少の大きな地点は仙台の (年 $0.1020 \mathrm{GJ}$ ) で, 次いで稚内, 網走の順 であり, 増加の大きな地点は長崎の (年 $0.0310 \mathrm{GJ}$ ) で, 次いで札幌, 東京の順である。増加の割合は減少の割合に比べて小さい。

\section{謝辞}

戸建住宅モデルの設定に際し工学院大学名誉教授宇田川弘光氏の ご指導を受けました。深謝致します。

\section{注}

注 1）設定温度が異なる熱負荷計算法 設定温度 2 点 $\theta_{r} ， \theta_{r}$, とすると

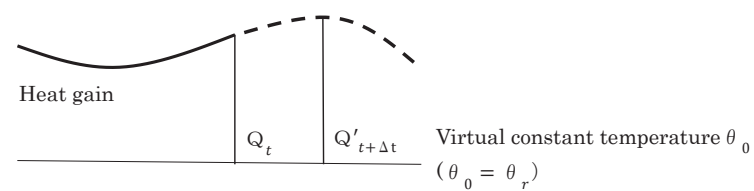

Heat storage load

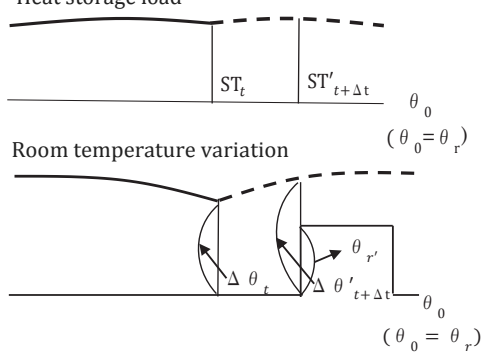

$\mathrm{t}$ 時の一定室温基準熱取得 $\mathrm{Q}_{t}$

蓄熱負荷 $S T_{t}=-\sum_{i=1}^{\infty} W F(i) \cdot \Delta \theta_{t-i \Delta t}$ とすると

$\theta_{0}$ 基準の仮想の顕熱負荷 $q_{t}=Q_{t}+S T_{t}$

仮想の室温変動 $\Delta \theta_{r}=q_{t} / W F(0)$ となり

空調の場合

顕熱負荷 $q_{t}=Q_{t}+S T_{t} \quad$ 室温 $\theta_{t}=\theta_{0}$

非空調 (自然室温) の場合

顕熱負荷 $q_{t}=0 \quad$ 室温 $\theta_{t}=\theta_{0}+q_{t} / W F(0)$

となる。

設定温度が $\left(\theta_{r^{\prime}}\right)$ の場合

$\theta_{0}$ 基淮の $\mathrm{t}+\Delta \mathrm{t}$ 時の仮想の顕熱負荷

$q_{t+\Delta t}^{\prime}=Q_{t+\Delta t}^{\prime}+S T^{\prime}{ }_{t+\Delta t} \quad$ となり

仮想の室温変動

設定温度差 $\Delta \theta_{r^{\prime}}=\theta_{r^{\prime}}-\theta_{r}$

空調の場合

顕熱負荷 $q^{\prime \prime}{ }_{t+\Delta t}=q_{t+\Delta t}^{\prime}-W F(0) \Delta \theta_{r^{\prime}} \quad$ 室温 $\theta_{t+\Delta t}=\theta_{r}+\Delta \theta_{r^{\prime}}=\theta_{r^{\prime}}$

非空調の場合

顕熱負荷 $q_{t+\Delta t}^{\prime}=0$ 室温 $\theta_{t+\Delta t}=\theta_{0}+\Delta^{\prime} \theta_{r}$

となる。

ただし

$W F(i): i$ 項のウェイティングファクタ $[\mathrm{W} / \mathrm{K}]$

$\theta_{0}:$ 仮想一定温度 $\left[{ }^{\circ} \mathrm{C}\right]$

$\Delta \theta_{r}^{\prime}=q_{t+\Delta t}^{\prime} / W F(0)$

注 2) 冬季暖房負荷とは 8 月 1 日から翌年の 7 月 31 日間での毎時気象デー 夕を用い, 暖房設定温度以下になると暖房負荷が生じるとし， 8 月 1 日の年の冬季暖房負荷と称する 同様に夏季冷房負荷とは 1 月 1 日から同年の 12 月 31 日迄の毎時気 象データを用い冷房設定温度以上になると冷房負荷が生じるとし， 1 月 1 日の年の夏季冷房負荷と称する。
1) Japan Meteorological Agency : Climate Change Monitoring Report 2016, 2016. 07

気象庁：気候変動監視レポート2016,2016.07

2) Hideki Takebayashi and Masashi Senoo : Analysis of the Relationship between the Size of Urban Located on Coastal and Heat Island Intensity in Summer by Using WRF Model, Journal of Environmental Engineering (Transaction of AIJ), Vol. 81 No.726, pp. 707-713, 2016.8 (in Japanese)

竹林英樹, 妹尾将司：メソ気象モデル WRF を用いた海岸に立地する都 市の規模と夏期のヒートアイランド強度の関係解析，日本建築学会環 境系論文集, Vol. 81, No. 726,pp. 707-713,2016.8

3) Yasunobu Ashie, Takayuki Tokairin and Takaaki Kono:High Resolution Numerical Simulation on the Urban Heat Island in a Ten-kilometer Square Area of Central TOKYO by Using the Earth Simulator, Journal of Environmental Engineering(Transaction of AIJ), No. 616, pp. 67-74, 2007.6 (in Japanese)

足永靖信，東海林孝幸，河野孝昭：地球シミュレータを用いた東京都 心 $10 \mathrm{~km}$ 四方における高解像度のヒートアイランド数值解析, 日本建築 学会環境系論文集, No.616,pp. 67-74,2007.6

4) Akira Hoyano and Jiang He: Numerical Analysis of the Summer and Winter Heat Island Potential for Various Urban Blocks, Journal of Environmental Engineering(Transaction of AIJ), (in Japanese), Vol. 74, No. 636, pp. 217-223, 2009. 2

梅干野 昆，何 江：熱収支シミュレーションによる市街地街区単位 の夏季と冬季ヒートアイランドポテンシャルの解析, 日本建築学会環 境系論文集, Vol. 74, No. 636,pp. 217-223, 2009.2

5) Kazuhiro Soga: Application to Air-Conditioning Load Calculation of Future Reference Weather Year Data Based on Global Warning ProjectionVol.6,AIJ Journal of Technology and Design, Vol. 21, No. 47, pp. 177-182,2015.2(in Japanese)

曽我和弘：地球温暖化予測情報第 6 巻に基づく標準年将来気象データ の空調熱負荷への応用， 日本建築学会技術報告集, Vol.21, No. 47, pp. 177-182, 2015. 2

6) Yusuke Arima, Ryuzo Ooka, Hideki Kikumoto and Toru Yamanata: A Prototype of Near Future Standard Weather Data and the Impact of Climate Change on Building Energy Load in KANTO Region in Summer, Journal of Environmental Engineering(Transaction of AIJ), Vol.80, No. 710, pp. 371379, 2015. 4(in Japanese)

有馬雄祐, 大岡龍三, 菊本英紀, 山中徹 : 夏季の関東地方を対象とし た近未来標準気象データの試作と気候変動の建築熱負荷への影響評価 力学的ダウンスケーリングによる建築熱負荷計算のための近未来気象 データの作成 (その 1), 日本建築学会環境系論文集, Vol. 80, No. 710, pp. 371-379, 2015. 4

7) Kyoichiro Isozaki and Hitoshi Takeda: Prediction of the Near Future Annual Cooling and Heating Loads Based on the Weather Indexes

Annual Cooling and Heating Loads Prediction of the Office From Past 50 years of Tokyo, Journal of Environmental Engineering (Transaction of AIJ), Vol.81, No. 726, pp. 669678, 2016.8 (in Japanese)

磯崎恭一郎，武田仁：気象指標に基づく近未来冷暖房負荷の予測 東 京の最近 50 年間よりのオフィス年間冷暖房負荷の予測, 日本建築学会 環境系論文集, vol. 81, No. 726,pp. 669-678,2016.8

8) Hiroshi Akasaka, Hideyo Nimiya et al: Expansion Weather Forecast Weather Data and Architectural Institute of Japan, 2000(in Japanese)

赤坂裕, 二宮秀興他 6 名：拡張アメダス気象データ, 日本建築学 会, 2000

9) Hitoshi Takeda and Kyoichiro Isozaki: Nationwide Meteorological Data and Thermal Load Calculation Program LESCOM, 2017.12(in Japanese)

武田仁, 磯崎恭一郎：全国気象データと熱負荷計算プログラム LESCOM, 井上書院，2017. 12

10) Japan Meteorological Agency:Past Weather Data Download, 
(accessed 2018.02.13)

気象庁 | 過去の気象データ・ダウンロード(閲覧 2018. 02.13)

www. data. jma. go. jp/gmd/risk/obsdl/index. php

11) Shinichi Matsumoto: Precision CalculationMethods for Solar Declination and Equation of Time, Architectual Institute of Japan, Summaries of Technical Papers of Annual Meeting,

Architectural Institute of Japan, Environmental EngineeringII, pp. 7-8, 2006.9 (in Japanese)

松本真一, 太陽視赤緯と均時差の計算精度の検討, 日本建築学会大会 学術講演梗概集, 環境工学 II , pp. 7-8, 2006, 9

12) D. T. Reindl, W. A. Beckman and J.A. Duffle: Diffuse Fraction Correlations, Solar Energy, Vol. 45, No, 1, pp. 1-7(1990)

13) Yoh Matsuo, Hiroshi Akasaka, Hisaya Ishino and Hiroshi Takizawa: Study on the Standard Weather Data, The Society of Heating, Air Conditioning and Sanitary Engineers of Japan, Vol. 48, No. 7, pp. 85107, 1974. 7 (in Japanese)

松尾陽, 赤坂裕, 石野久弥, 滝沢博: 標準気象データに関する研究, 空 気調和・衛生工学, Vol. 48, No. 7, pp. 85-107, 1974.7

14) Michihiro Udagawa: Proposal of Standard Problem (Standard Problem for House), Current Status and Problems of Heat Transfer Analysis, Environmental Engineering Committee, pp. 23-33, 1985.9(in Japanese) 宇田川光弘：標準問題の提案（住宅用標準問題）, 熱分科会第 15 回熱 シンポジウム, pp. 23-33, 日本建築学会環境工学委員会, 1985

15) Hitoshi Takeda, Hirokazu Suzuki and Sin Hayakawa:Thermal Characteristics of an Opening with Solar Radiation Shading Evaluation of 0ptical Characteristics on Venetian Blind and Thermal Characteristics Regarding an Air Space, Journal of Environmental Engineering (Transaction of AIJ), Vol. 79, №. 706, pp. 1037-1047, 2014. 12 (in Japanese)

武田仁, 鈴木宏和, 早川眞 : 開口部の日射遮蔽物による熱特性一ベネシ アンブラインドの光学特性および中空層の熱特性の検証一, 日本建築 学会環境系論文集, Vol. 79, No. 706, pp. 1037-1047, 2014.12

16) Hitoshi Takeda:Application of Phase Change Material (PCM) to Building Heating Verification of Room Temperature Fluctuation Constructed by Wall with Built-in PCM Bag, Journal of Environmental Engineering (Transaction of AIJ), Vol. 80, No. 718, pp. 1115-1123, 2015. 12 (In Japanese)

武田仁：潜熱蓄熱材（PCM）の建物暖房への適用一潜熱蓄熱材壁で構成 されたスペースの室温変動解析一, 日本建築学会環境系論文集, Vol. 80, No. 718, pp. 1115-1123, 2015. 12 


\title{
ANALYTICAL STUDY OF COOLING AND HEATING LOADS \\ DUE TO RECENT NATIONWIDE WEATHER DATA
}

Changes in cooling and heating loads and peak loads of the detached house during the year from 1991 to 2017

\author{
Kyoichiro ISOZAKI ${ }^{* 1}$ and Hitoshi TAKEDA*2 \\ ${ }^{* 1}$ LESCOM Institute Co., Ltd. \\ ${ }^{* 2}$ Prof. Emeritus, Tokyo University of Science, Dr.Eng.
}

According to the Meteorological Agency 'Climate Change Monitoring Report 2016', the average annual temperature in Japan has risen.

The urban area reports that it is improving the heat island.

The authors focused on the influence of recent weather changes on cooling and heating load.

The heating and cooling loads are calculated from weather change and building condition, internal heat generation, air conditioning driving situation.

The authors created data from JMA observation data of 30 locations nationwide from 1991 to 2017 (27 years) recently for heat load calculation.

Using these data, the cooling and heating loads of the detached house were strictly calculated using the thermal load calculation program (LESCOM-mint).

\section{Summary}

(1) Annual cooling loads increase both in cities and elsewhere.

The biggest point of increase is Fukuoka's year 0.838 GJ, followed by Nagasaki, Ishigaki-jima,Cyoshi, Tokyo.

(2) Annual heating loads are decreasing due to secular change, but there are some points where it is increasing.

This is because the outside air temperature that greatly affects the heating load does not necessarily increase due to secular change.

The major reduction point is Sendai's year 0.102 GJ, followed by Wakkanai, Abashiri, Kagoshima, Morioka. The biggest point of increase is 0.0316 GJ in Nagasaki year, then Sapporo, Tokyo, Niigata and Nagoya.

The rate of increase is small compared to the rate of decrease.

(3) The instantaneous cooling loads increase at 29 locations, excluding one point Kofu.

The biggest point of increase is Hakodate year $0.0338 \mathrm{~kW}$, followed by Morioka, Ishigaki-jima, Aomori, Akita in order. Kofu is decreasing, but it is very small with a decrease of $0.0061 \mathrm{~kW}$ a year.

(4) The instantaneous heating loads are increasing and decreasing over time.

The increase is due to the fact that the fluctuation of the outside air temperature in the extremely cold season in winter is different from year to year, and it does not rise monotonically with aging.

The major point of decrease is $0.0663 \mathrm{~kW}$ of Ishigaki-jima, then Miyakojima, Aomori, Naze, Abashiri in order.

The biggest point of increase is Nagasaki's year $0.0632 \mathrm{~kW}$, followed by Hiroshima, Matsuyama, Kumamoto and Osaka. 